\title{
PENGARUH PENGGUNAAN MEDIA POP-UP TERHADAP KETERAMPILAN MENULIS DESKRISI TEMA BUMI DAN ALAM SEMESTA SISWA KELAS III SDIT AT-TAQWA SURABAYA
}

\author{
Fenny Tanalinal Khasna ${ }^{1}$, Abdul Syahril Muh ${ }^{2 *}$ \\ PGSD, FKIP, Universitas Muhammadiyah Kupang ${ }^{1}$ \\ PGSD, FKIP, Universitas Muhammadiyah Kupang ${ }^{2}$ \\ E-mail: fennytanalinal@gmail.com, syahrilabdu145@gmail.com
}

\begin{abstract}
Abstrak
Tujuan penelitian ini untuk mengetahui pengaruh penggunaan media $p o p$ - up dalam keterampilan menulis deskripsi dan pengaruh penggunaan media $p o p$ - $u$ p terhadap keterampilan menulis deskripsi siswa kelas III SDIT At-Taqwa Surabaya. Jenis penelitian yang digunakan adalah pre-experimental design. Rancangan penelitianyang digunakan adalah one group pretest-posttest design.

Pengumpulan data dilakukan dengan observasi dan tes (pretest dan posttest). Instrumen yang digunakan adalah lembar observasi penggunaan media pop-up dalam pembelajaran menulis deskripsi dan soal tes tentang deskripsi. Teknik analisis data dimulai dari uji validitas instrumen observasi dan instrumen tes.

Data yang diperoleh diolah dengan statistik parametrik dan uji-t. Pada uji-t

diperoleh hasil diketahui bahwa harga $t_{\text {hitung }}$ lebih besar daripada harga $t_{\text {tabel }}(10,027>2,060)$. Berdasarkan hasil yang diperoleh maka dapat disimpulkan bahwa terdapat pengaruh yang signifikan penggunaan media pop-up terhadap keterampilan menulis deskripsi siswa.
\end{abstract}

\begin{abstract}
The purpose of this study was to determine the effect of pop-up media application in description writing skills and the influence of pop-up media application on the descriptive writing skills of grade III students of SDIT At-Taqwa Surabaya. The type of research used was pre-experimental design. The research design used was one group pretest-posttest design. Data collection was carried out by observation and tests (pretest and posttest). The instrument used was the observation sheet using pop-up media in learning to write descriptions and test questions about descriptions. The data analysis technique starts with the validity test of the observation instrument and the test instrument. The data obtained were processed with parametric statistics and t-test. In the t-test, the results showed that the t-count price is greater than the t-table price (10.027> 2.060). Based on the results obtained, it can be concluded that there is significant effect of using pop-up media on students' description writing skills.
\end{abstract}

Keywords: pop-up media, description writing skill.

\section{PENDAHULUAN}

Pendidikan merupakan pintu gerbang kemajuan suatu bangsa. Dunia pendidikan terus berkembang seiring dengan perkembagan zaman yang ada. Tuntutan akan kualitas sumber daya manusia akan terus mengalami perubahan secara dramatis. Dunia pendidikan harus terus menyusaikan dengan perkembangan zaman agar mampu menyediakan output yang berkualitas sesuai dengan tuntutan kebutuhan. Pendidikan dituntut menyediakan manusia yang memiliki intelektualitas tinggi,terampil dan berbudi luhur.

Undang-undang No 32 Tahun 2013 tentang sistem pendidikan nasional (sisdiknas), menyebutkan bahwa kurikulum adalah seperangkat rencana dan pengaturan mengenai tujuan, isi dan bahan belajar serta cara yang digunakan sebagai pedoman penyelenggaraan kegiatan pembelajaran untuk mencapai tujuan pendidikan tertentu, oleh karena itu untuk mewujudkan pendidikan yang bermutu membutuhkan upaya terus menerus agar kualitas pendidikan selalu meningkat. 
Pendidikan abad ke-21 adalah mendorong peserta didik agar menguasai keterampilanketerampilan yang penting dan berguna bagi mereka agar lebih resposif terhadap perubahan dan perkembangan zaman, termasuk didalamnya memperoleh keterampilan berbahasa yakni dengan cara melalui hubungan urutan yang teratur, mula-mula pada masa kecil belajar menyimak bahasa kemudian berbicara, sesudah itu belajar membaca dan menulis (Afandi, 2016). Salah satu mata pelajaran yang diintegrasikan dalam kurikulum 2013 adalah bahasa Indonesia. Bahasa Indonesia merupakan bahasa pemersatu yang hampir semua masyarakat mengetahuinya. Oleh karena itu, setiap manusia harus menguasai bahasa persatuan mereka. Bahasa juga memiliki peranan penting dalam perkembangan peserta didik, baik perkembangan sosial, intelektual maupun emosional. Bahasa menjadi salah satu penunjang dalam keberhasilan berbagai bidang studi yang dipelajari peserta didik. Dalam pembelajaran bahasa Indonesia diarahkan untuk meningkatkan kemampuan peserta didik untuk berkomunikasi dengan bahasa Indonesia baik secaralisan maupun tertulis, serta menimbulkan penghargaan terhadap hasil cipta manusia Indonesia. Pembelajaran bahasa Indonesia juga diarahkan untuk meningkatkan keterampilan berbahasa yang dimiliki peserta didik.

Ruang lingkup bahasa Indonesia mencakup aspek kebahasaan dan aspek keterampilan berbahasa yang saling berkaitan. Aspek kebahasaan meliputi struktur kata dan ejaan, sedangkan keterampilan berbahasa dalam kurikulum di SD mencakup empat aspek. Menurut Tarigan (2008: 1), empat keterampilan tersebut yaitu keterampilan menyimak (listening skill), keterampilan berbicara (speaking skill), keterampilan membaca (reading skill), keterampilan menulis (writing skill). Setiap keterampilan itu erat sekali berhubungan dengan ketiga keterampilan lainnya dengan cara yang beraneka ragam. Salah satu aspek penting dalam keterampilan berbahasa di SD yang harus dikuasai siswa adalah keterampilan menulis. Keterampilan menulis selalu ada dalam setiap kompetensi dasar pada pembelajaran bahasa Indonesia. Menulis merupakan salah satu aspek keterampilan penting dalam kehidupan, karena setiap kegiatan di sekolah atau di masyarakat tidak lepas dari kegiatan menulis. Dengan menulis seseorang dapat mengeluarkan gagasan dan pikirannya dalam bentuk tulisan dan seseorang dapat berkomunikasi melalui tulisan. Menulis dibagi menjadi beberapa macam berdasarkan cara penyajian dan tujuan penulisan. Salah satunya yaitu menulis deskripsi.

Untuk menunjang tercapainya keterampilan tersebut, peran guru dalam pembelajaran menulis diperlukan, terutama pada media yang digunakan oleh guru. Media pembelajaran telah menjadi bagian integral dalam pembelajaran. Bahkan keberadaannya tidak dapat dipisahkan dalam proses pembelajaran di sekolah. Media dapat meningkatkan pengetahuan, memperluas pengetahuan, serta memberikan fleksibilitas dalam penyampaian pesan. Selain itu, media juga berfungsi sebagai alat komunikasi, sebagai sarana pemecahan masalah dan sarana pengembangan diri.

Di dalam proses pembelajaran, seorang guru tentunya memahami tentang alat bantu atau media apa yang akan dibutuhkan dalam menyampaikan materi kepada siswanya. Media pembelajaran sangat berpengaruh dalam kegiatan belajar mengajar, terutama dalam meningkatkan kemampuan dan minat belajar siswa. Media memegang peranan penting sebagai alat bantu untuk menciptakan situasi belajar yang lebih baik dan efisien. Oleh karena itu, guru mengajarkan kepada siswa dengan menggunakan media sangatlah penting dan memberi dampak positif terhadap cara belajar siswa. Salah satu media yang dapat digunakan dalam menulis deskripsi yaitu media pop-up. Penggunaan media pop-up ini bertujuan untuk mengembangkan kemampuan siswa dalam menulis deskripsi. Tidak hanya menulis saja, dengan menggunakan media рор-up siswa dapat mengembangkan kemampuan berbicara dan menyimak pada aspek kebahasaannya.

Pop-up dapat digunakan sebagai contoh untuk menjelaskan konsep-konsep yang sangat abstrak dan memerlukan objek yang konkret pada beberapa mata pelajaran. Media Pop-up ini 
diharapkan mampu meningkatkan keterampilan siswa untuk menulis suatu deskripsi melalui kegiatan pengamatan dan berperan langsung pada media. Hal ini dapat memberikan inspirasi dan masukan guru untuk lebih mengembangkan kreatifitas dalam penggunaan media saat pembelajaran berlangsung. Penggunakan media pop-up dalam pembelajaran dapat memberikan visualisasi cerita yang lebih menarik mulai dari tampilan gambar yang terlihat lebih memiliki dimensi hingga gambar yang bergerak ketika halamannya dibuka. Selain itu, media pop-up juga dapat mengatasi batasan ruang, waktu, dan pengamatan karena tidak semua benda, objek atau peristiwa dapat dibawa ke dalam kelas atau siswa dapat mengamati peristiwa objek tersebut (Dzuanda, 2011). Media pop-up digunakan agar siswa lebih mudah dalam menulis suatu deskripsi, mengerti bagaimana cara penulisan karangan deskripsi yang tepat dengan menggunakan ejaan yang benar, dan dapat mengembangkan ide yang kreatif untuk menjadikannya sebuah kalimat dan merangkai kalimat tersebut menjadi sebuah deskripsi sehingga sesuai dengan tujuan pembelajaran. Media pop-up adalah inovasi media pembelajaran berbentuk dua lapis kertas tertutup, yang ketika dibuka isi (tampilan) di dalamnya akan terangkat lebih jelas dan memiliki unsur tiga dimensi. Tampilan visual yang lebih berdimensi membuatnya semakin terasa nyata di tambah lagi dengan kejutan yang diberikan dalam setiap halamannya. Gambar dapat secara tiba-tiba muncul dari balik halaman atau sebuah bangunan dapat berdiri megah ditengah-tengah halaman dengan cara pemvisualisasian ini, kesan yang ingin ditampilkan dapat lebih tersampaikan.

Adapun kreasi lain pada pop up yaitu pop up book dan pop up card. Pada pop up book ini hampir sama dengan pop up card hanya saja tampilan dalam atau isinya berbeda. Pop up book berisi tentang cerita bersambung sedangkan pop up card hanya satu materi tanpa bersambung artinya didalam kartunya terdapat suatu gambar. Dzuanda (2011) menjelaskan pengertian Pop-up book merupakan sebuah buku yang memiliki bagian yang dapat bergerak atau memiliki unsur 3 dimensi serta memberikan visualisasi cerita yang lebih menarik, mulai dari tampilan gambar yang dapat bergerak ketika halamannya dibuka. Pop-up berpotensi untuk dikembangkan sebagai bahan ajar karena memiliki kelebihan, seperti yang dikemukakan oleh Dzuanda (2011) antara lain : (1) dapat mengatasi batasan ruang, waktu, dan pengamatan karena tidak semua benda, objek atau peristiwa dapat dibawa ke dalam kelas atau siswa dapat mengamati peristiwa objek tersebut. (2) Memberikan visualisasi cerita yang lebih menarik mulai dari tampilan gambar yang terlihat lebih memiliki dimensi hingga gambar yang bergerak ketika halamannya dibuka. (3) memberikan kejutan-kejutan dalam setiap halamannya yang dapat mengundang ketakjuban ketika halamannya dibuka, sehingga pembaca menanti kejutan apalagi yang akan diberikan di halaman selanjutnya (4) Bersifat konkret, yang berarti lebih realistis dari pada media verbal.

\section{METODE}

Jenis penelitian ini adalah jenis penelitian pre-experimental design. Penelitian ini menggunakan jenis pre-experimental design, karena dalam penelitian ini bertujuan untuk mengungkapkan adanya pengaruh dari penggunaan media pop-up terhadap keterampilan menulis deskripsi jika dibandingkan dengan pembelajaran yang tidak menggunakan media рор-ир.

Rancangan penelitian yang digunakan adalah one group pretest-posttest design. Penelitian tidak menggunakan kelas pembanding namun menggunakan tes awal sehingga besarnya efek atau pengaruh penggunaan media pop-up dapat diketahui secara pasti. Dalam penelitian ini, subyek penelitian terlebih dahulu diberikan tes awal (pretest) untuk mengetahui sejauh mana kemampuan awal siswa sebelum diberikan pembelajaran bahasa Indonesia tentang menulis deskripsi dengan menggunakan media pop-up. Setelah diberikan tes awal, selanjutnya siswa tersebut diberikan perlakuan, yaitu pada saat pembelajaran dengan memberikan media pop-up yang berisikan berbagai macam gambar. Setelah selesai 
pembelajaran dengan menggunakan media, selanjutnya seluruh siswa diberikan tes akhir (posttest) untuk mengetahui sejauh mana pengaruh pembelajaran yang dilakukan dengan menggunakan media pop-up terhadap kemampuan menulis deskripsi siswa. Alasan menggunakan design ini karena desain ini dianggap lebih ringan dalam pelaksanaan perlakuan pada penelitian eksperimen.

Penelitian ini dapat digambarkan sebagai berikut:

\section{$\mathrm{O}_{1} \mathrm{X} \mathrm{O}_{2}$}

Keterangan :

$\mathrm{O}_{1}$ : tes awal (pretest)

$\mathrm{O}_{2}$ : tes akhir (posttest)

$\mathrm{X}$ :Perlakuan (pembelajaran diberikan media pop-up)

(Sugiyono,2010)

Penelitian ini dilaksanakan di SDIT At-Taqwa Surabaya. Pada penelitian ini yang menjadi populasi adalah siswa kelas III SDIT At-Taqwa Surabaya, sedangkan yang menjadi sampel penelitian adalah siswa kelas III-B dengan jumlah 26 siswa. Variabel dalam penelitian ini yaitu variabel bebasnya adalah media popup, variabel terikatnya adalah keterampilan menulis deskripsi.

Instrumen yang digunakan dalam penelitian ini terdiri atas instrumen observasi dan tes (pretest dan posttest). Observasi dilakukan untuk mengamati peneliti sebagai guru pelaksana pembelajaran saat melakukan kegiatan belajar mengajar. Observasi dilakukan pada penggunaan media pop-up dalam pembelajaran menulis deskripsi kelas III SDIT At-Taqwa Surabaya agar mengetahui pengaruh penggunaan media pop-up terhadap keterampilan menulisdeskripsi.Lembar tes yang digunakan dalam penelitian ini berupa pretest dan posttest yang berkaitan dengan menulis deskripsi. Butir soal yang dikembangkan berupa soal uraian terbuka. Pertanyaan yang diberikan meliputi menulis bagian bangunanbangunan rumah adat yang ada pada gambar yang telah diberikan dan mengembangkan bagian bangunanbangunan tersebut menjadi sebuah deskripsi. Dari test tersebut, maka akan diperoleh hasil menulis deskripsi pada pretest dan akan dibandingkan pada hasil posttest.

Teknik analisis data dimulai dari uji validitas instrumen observasi dan instrumen tes. Validitas butir soal yaitu suatu ukuran yang menunjukkan tingkat-tingkat kevalidan atau kesahihan suatu instrumen. Suatu instrumen yang valid akan mempunyai validitas tinggi dan sebaliknya instrumen yang kurang valid berarti memiliki validitas rendah. Uji validitas yang digunakan yaitu validitas konstruk dan validitas isi. Validitas konstruk dilakukan dengan konsultasi dengan pakar atau ahli, sedangkan validitas isi dilakukan dengan membandingkan isi instrumen dengan isi atau rancangan yang telah ditetapkan ditambah dengan konsultasi kepada ahli atau pakar. Berikutnya untuk butir pertanyaan akan diuji validitasnya dengan konsultasi kepada ahli dan dilanjutkan dengan mengujicobakan kepada siswa lalu dianalisis dengan menggunakan teknik korelasi product moment. Adapun rumus yang digunakan sebagai berikut:

$r_{x y}=\frac{N \sum X Y-\left(\sum X\right)\left(\sum Y\right)}{\sqrt{\left\{N \sum X^{2}-\left(\sum X^{2}\right)\right\}\left\{N \sum Y^{2}-\left(\sum Y^{2}\right)\right\}}}$

Keterangan:

$\mathrm{r}_{\mathrm{xy}}$ : koefisien korelasi antara variabel $\mathrm{X}$ dan variabel $\mathrm{Y}$

$\mathrm{X}$ : skor tiap butir soal

$\mathrm{Y}$ : skor soal

$\mathrm{N}$ : banyaknya siswa

(Arikunto, 2010) 
Setelah nilai pengujian setiap butir soal diperoleh, selanjutnya nilai tersebut dibandingkan dengan $r_{\text {tabel }}$. Jika nilai $r_{\text {hitung }}>r_{\text {tabel }}$, maka butir soal dinyatakan valid dan dapat digunakan sebagai instrumen penelitian.

Uji data selanjutnya yaitu uji reliabilitas, pengujian ini menunjukan suatu instrumen cukup dapat dipercaya atau tidak untuk digunakan sebagai alat pengumpulan data penelitian. Uji reliabilitas instrumen dalam penelitian ini adalah uji reliabilitas instrumen observasi dan instrumen penilaian tes keterampilan menulis deskripsi. Tingkat reliabilitas instrumen observasi dapat diukur dengan memberikan format penilaian reliabilitas beserta rubrik penilaiannya kepada pengamat I dan pengamat II saat mengamati proses pembelajaran keterampilan menulis deskripsi dengan menggunakan media pop-up. Langkah yang dilakukan dalam melakukan reliabilitas ini yaitu menjajarkan format isian dari pengamat I dan pengamat II. Kemudian pengamatan dimasukkan dalam tabel kontingensi kesepakatan. Sedangkan uji reliabilitas untuk instrumen penilaian tes menggunakan rumus koefisien reliabilitas Alpha Cronbach. Adapun rumusnya sebagai berikut:

$$
\begin{aligned}
& r_{11}=\left(\frac{k}{k-1}\right)\left(1-\frac{\sum \sigma_{\mathrm{t}}^{2}}{\sigma_{\mathrm{t}}^{2}}\right) \\
& \text { Keterangan : } \\
& r_{11}=\text { reliabilitas instrumen } \\
& k=\text { banyaknya butir pertanyaan atau banyaknya butir } \\
& \text { soal } \\
& \Sigma \sigma_{t}^{2}=\text { jumlah varians butir } \\
& \sigma_{t}^{2} \quad=\text { varians total (Arikunto, 2013) }
\end{aligned}
$$

Rumus untuk mencari varians adalah:

$$
\sigma_{t}^{2}=\frac{\Sigma x^{2}}{\mathbb{N}}-\left[\frac{\Sigma y^{2}}{[\mathbb{N}}\right]^{2}
$$

$$
\begin{array}{ll} 
& \text { Keterangan : } \\
\sigma_{\mathrm{t}}^{2} & =\text { varians soal } \\
\mathbb{X}^{2} & =\text { jumlah nilai keseluruhan } \\
N & \quad=\text { jumlah sampel }
\end{array}
$$

Apabila sudah memperoleh angka reliabilitas, langkah selanjutnya adalah membandingkan harga tersebut dengan tabel $\mathrm{r}$ product moment pada taraf signifikansi $5 \%$. Jika $\mathrm{r}_{11}<\mathrm{r}_{\text {tabel }}$ maka hasilnya tidak reliabel, tetapi jika $\mathrm{r}_{11}>\mathrm{r}_{\text {tabel }}$ maka hasilnya reliabel.

Tabel 1 Interpretasi Reliabilitas

\begin{tabular}{|l|l|}
\hline Besarnya Koefisien & Kriteria \\
\hline $0,80<\mathrm{r}_{11} \leq 1,00$ & Sangat tinggi \\
\hline $0,60<\mathrm{r}_{11} \leq 0,80$ & Tinggi \\
\hline $0,40<\mathrm{r}_{11} \leq 0,60$ & Cukup \\
\hline $0,20<\mathrm{r}_{11} \leq 0,40$ & Rendah \\
\hline$-1<\mathrm{r}_{11} \leq 0,20$ & Sangat rendah \\
\hline
\end{tabular}

Instrumen yang sudah dinyatakan valid dan reliabel dapat digunakan untuk mengambil data di lapangan. Data yang digunakan dalam penelitian ini adalah soal tes uraian keterampilan 
menulis deskripsi. Data yang telah diperoleh dari hasil melakukan penelitian di lapangan setelah itu harus diuji normalitas terlebih dahulu sebelum dilakukan uji t-test.

Uji normalitas bertujuan untuk mengetahui apakah data yang diperoleh berdistrbusi normal atau tidak. Uji normalitas merupakan syarat yang harus dipenuhi untuk menentukan uji statistik yang akan digunakan. Dalam penelitian ini, peneliti menghitung uji normalitas dengan menggunakan rumus Chi- square. Menurut winarsunu (2012) chi-square digunakan untuk menafsir apakah ada perbedaan yang signifikan atau tidak antara frekuensi yang diperoleh dengan frekuensi yang diharapkan. rumus yang digunakan sebagai berikut:

$$
x^{2}=\Sigma\left[\frac{(f o-f e)^{2}}{f e}\right]
$$

Keterangan :

$x^{2}=$ nilai

chi-square fo $=$ frekuensi yang diperoleh (obtained frequency)

$f e=$ frekuensi yang diharapkan (expected frequency)

(Winarsunu, 2012)

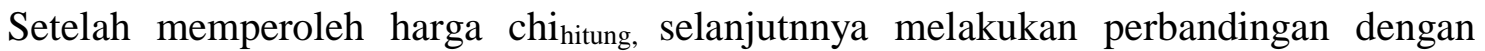
ketentuan harga chi hitung $_{\text {dengan }}$ chitabel. Jika chi $_{\text {hitung }}$ sama dengan atau kurang dari chi tabel maka

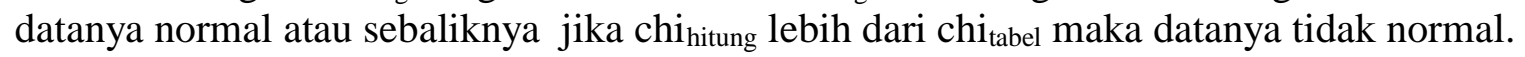

Untuk data selanjutnya adalah uji hipotesis. Uji hipotesis ini dilakukan untuk mengetahui pengaruh media pop-up terhadap keterampilan menulis deskripsi siswa. Berdasarkan desain yang digunakan dalam penelitian ini, yaitu menggunakan one group pretest-posttest design, maka analisis data dilakukan dengan menggunakan rumus sebagai berikut:

$$
t=\frac{M d}{\sqrt{\frac{\sum x^{2} d}{N[N-1]}}}
$$

Keterangan :

$\mathrm{Md} \quad=$ mean dari perbedaan pre-test dengan post-test

$\mathrm{xd} \quad=$ deviasi masing-masing subjek $(\mathrm{d}-\mathrm{Md})$

$\Sigma x^{2} d=$ jumlah kuadrat deviasi $\mathrm{N}=$ subjek pada sampel

d.b. = ditentukan dengan N-1

(Arikunto, 2010)

Setelah diperoleh hasil dari penghitungan menggunakan rumus tersebut, kemudian dikonsultasikan dengan tabel nilai t. Perbedaan antara hasil nilai pretest dan post-test dapat dikatakan signifikan jika $t_{\text {hitung }} \geq \mathrm{t}_{\text {tabel }}$ pada taraf signifikansi $5 \%$.

\section{HASIL DAN PEMBAHASAN}

Pelaksanaan penelitian eksperimen dilakukan dari tahap analisis prasyarat yang berupa uji validitas ahli. Instrumen yang divalidasikan yaitu instrumen perangkat pembelajaran, soal pretest dan posttest, media pop-up. Selain uji validitas ahli, terdapat uji validitas tes yang diberikan kepada siswa dengan analisis menggunakan rumus product moment. Berikut ini adalah perhitungan uji validitas yang dilakukan pada siswa kelas III di SDIT AtTaqwa Surabaya. 
Tabel 2 Hasil Perhitungan Uji Validitas Soal

\begin{tabular}{|l|l|l|l|}
\hline No.Soal & rhitung & Rtabel & Keterangan \\
\hline 1. & 0,526 & 0,374 & Valid \\
\hline 2. & 0,809 & 0,374 & Valid \\
\hline 3. & 0,875 & 0,374 & Valid \\
\hline
\end{tabular}

Dari data tersebut, diketahui bahwa seluruh nilai koefisien korelasi dari 3 butir soal lebih besar dari nilai korelasi tabel. Jadi dapat diketahui bahwa soal untuk menulis deskripsi valid. Analisis data selanjutnya yaitu uji reliabilitas. Uji reliabilitas berupa instrumen observasi dan instrumen tes. Reliabilitas suatu instrumen observasi menggunakan lembar observasi yang diamati oleh pengamat I dan pengamat II. Hasil perhitungan reliabilitas instrumen observasi dengan cara menghitung banyaknya kecocokan dari pengamat I dan pengamat II pada tabel kontingensi kesepakatan. Tabel kontingensi kesepakatan sebagai berikut:

Tabel 3 Tabel Kontingensi Kesepakatan

\begin{tabular}{|c|c|c|c|c|c|c|}
\hline \multirow{7}{*}{$\begin{array}{l}\text { Penga } \\
\text { mat II }\end{array}$} & \multicolumn{6}{|c|}{ Pengamat I } \\
\hline & & 1 & 2 & 3 & 4 & $\begin{array}{c}\text { Jumlah } \\
\text { pengamatan }\end{array}$ \\
\hline & 1 & & & & & 0 \\
\hline & 2 & & & & & 0 \\
\hline & 3 & & & & 13,26 & 2 \\
\hline & 4 & & & 4,11 & $\begin{array}{c}1,2,3,4,6,7, \\
8,9,10,12, \\
14,15.16,17, \\
18,19,20,21, \\
22,23,24,25, \\
26,27,29,30, \\
31,32,33,34, \\
35 .\end{array}$ & 33 \\
\hline & Jumlah amatan & 0 & 0 & 2 & 33 & 35 \\
\hline
\end{tabular}

Angka hasil perhitungan adalah 0,943. Jika dilihat pada tabel interpretasi koefisien reliabilitas (pada bab III), maka instrumen observasi pembelajaran menulis deskripsi dengan menggunakan media pop-up termasuk dalam derajat reliabilitas sangat tinggi. Untuk mengetahui reliabilitas suatu instrumen tes menggunakan menggunakan data hasil tes yang dihitung dengan rumus Alpha Cronbach. Jika harga $\mathrm{r}_{11}>\mathrm{r}_{\text {tabel }}$ maka soal dikatakan reliabel dengan taraf signifikan 5\%. Dari perhitungan dengan rumus Alpha Cronbach diperoleh $\mathrm{r}_{11}=$ 0,666 dan dapat dikonsultasikan dengan tabel $n=28-2=26$. Diketahui harga $r_{\text {tabel }}$ untuk taraf signifikan 5\% adalah 0,388. Dapat disimpulkan bahwa harga $r_{11}$ lebih besar daripada harga $r_{\text {tabel }}$ yaitu 0,666 > 0,388 maka instrumen tes dinyatakan reliabel dan termasuk dalam derajat reliabilitas tinggi. Reliabel artinya instrumen tes tersebut apabila digunakan sampai beberapa kali hasilnya akan tetap sama atau bisa diartikan dapat dipercaya. 
Selanjutnya uji normalitas. Untuk melakukan perhitungan uji normalitas. Peneliti menghitung hasil data pretest dan posttest dengan menggunakan rumus ChiSquare. Berikut ini merupakan hasil perhitungan uji normalitas data:

Tabel 4 Hasil Perhitungan Uji Normalitas

\begin{tabular}{|c|c|c|c|c|c|}
\hline $\begin{array}{c}\text { N } \\
\text { o. }\end{array}$ & Data & $\begin{array}{c}\text { Hasil } \\
\text { Chisquare } \\
\text { Hitun g }\end{array}$ & $\begin{array}{c}\text { Hasil Chi Square } \\
\text { Tabel }\end{array}$ & Perbandingan & Kesimpulan \\
\hline 1. & Pretest & 5,88 & 11,070 & chihitung<chitabl e & Normal \\
\hline 2. & Posttest & 10,53 & 11,070 & chihitung<chitabl e & Normal \\
\hline
\end{tabular}

Dari tabel di atas dapat disimpulkan bahwa data kelas eksperimen berdistribusi normal. Hal tersebut dapat dilihat pada kolom perbandingan bahwa semua data memperoleh hasil chi ${ }_{\text {hitung }}<$ chitabel pada taraf signifikansi $5 \%$ yang artinya data tersebut berdistribusi normal. Uji selanjutnya yaitu melakukan uji hipotesis. Uji ttest dilakukan dengan menghitung selisih atau beda hasil posttest dan pretest. Dari hasil perhitungan, diperoleh nilai thitung sebesar 10,027. Dengan $\mathrm{db}=25$, pada taraf signifikansi 5\% diperoleh $\mathrm{t}_{\text {tabel }}$ sebesar 2,055. Maka dapat disimpulkan bahwa $t_{\text {hitung }}>\mathrm{t}_{\text {tabel }}(10,027>2,055)$ artinya $\mathrm{H}_{0}$ tidak terbukti dan $\mathrm{H}_{1}$ terbukti. $\mathrm{H}_{0}$ yang menyatakan bahwa tidak terdapat perbedaan signifikan antara hasil menulis deskripsi siswa dengan menggunakan media pop-up; $\mathrm{H}_{1}$ yang menyatakan bahwa terdapat perbedaan signifikan antara menulis deskripsi siswa dengan menggunakan media pop-up, Sehingga dapat disimpulkan bahwa $\mathrm{H}_{1}$ yang menyatakan bahwa terdapat perbedaan signifikan antara hasil menulis deskripsi siswa dengan menggunakan media pop-up dengan yang tidak menggunakan perlakuan (media pop-up) diterima, artinya media pop-up berpengaruh terhadap keterampilan menulis deskripsi siswa kelas III SDIT At-Taqwa Surabaya.

\section{Pembahasan}

Penelitian eksperimen ini dilaksanakan di SDIT At-Taqwa Surabaya. Pembelajaran dilakukan pada satu kelas yaitu kelas III-B sebagai kelas eksperimen. Pada kelas eksperimen diberikan perlakuan berupa penggunaan media pop-up dalam pembelajaran menulis deskripsi. Berdasarkan data dan analisis hasil penelitian yang telah disampaikan, maka akan dibahas lebih lanjut mengenai hasil uji validitas, reliabilitas dan normalitas, keterlaksanaan dan ketercapaian pembelajaran dan uji hipotesis.

Hasil uji validitas instrumen menunjukkan hasil bahwa instrumen yang akan digunakan dalam penelitian dinyatakan valid, sehingga layak untuk digunakan. Uji validasi yang digunakan adalah judgment experts dengan meminta pendapat ahli tentang perangkat pembelajaran, tes dan media. Hasil dari para ahli direkapitulasi dan semuanya memberi keputusan instrumen layak dan dapat digunakan. Kemudian instrumen tes tersebut diuji cobakan di sekolah lain untuk mengetahui kevalidan soal. Uji validitas instrumen soal tes menggunakan rumus korelasi pearson dan menunjukkan hasil bahwa soal tes tersebut valid. Hasil validitas soal nomor 1 diperoleh hasil 0,526. Hasil validitas soal nomor 2 diperoleh hasil 0,809 dan validitas soal nomor 3 diperoleh hasil 0,875 . Hasil $r_{\text {hitung }}$ tersebut berada di atas $r_{\text {tabel }}$ yaitu 0,374 . Jadi $r_{\text {hitung }}>r_{\text {tabel }}$ dan dinyatakan valid.

Setelah melakukan perhitungan uji validitas dan memperoleh sejumlah soal yang valid, tahap selanjutnya melakukan uji reliabilitas terhadap soal. Uji reliabititas bertujuan untuk mengetahui bahwa instrumen penelitian yang dibuat cukup dapat dipercaya untuk digunakan sebagai alat pengumpul data. Untuk melakukan uji reliabilitas, peneliti menggunakan reliabilitas instrumen observasi dan instrumen tes. Pada reliabilitas suatu instrumen observasi 
peneliti menggunakan lembar observasi yang diamati oleh pengamat I dan pengamat II. Hasil perhitungan reliabilitas instrumen observasi dilakukan dengan cara menghitung banyaknya kecocokan dari pengamat Idan pengamat II pada tabel kontingensi kesepakatan. Angka hasil perhitungan adalah 0,943. Jika dilihat pada tabel interpretasi koefisien reliabilitas, maka instrumen observasi pembelajaran menulis deskripsi dengan menggunakan media pop-up termasuk dalam derajat reliabilitas sangat tinggi, yaitu berada pada rentang 0,80 - 1,00. Sedangkan Hasil uji reliabilitas instrumen soal tes deskripsi menunjukkan hasil 0,666. Hasil perhitungan tersebut juga termasuk dalam derajat reliabilitas tinggi. Dengan demikian, dapat disimpulkan bahwa instrumen-instrumen yang digunakan reliabel dan terpercaya.

Setelah melakukan uji reliabilitas, selanjutnya melakukan perhitungan uji normalitas. Dalam melakukan uji normalitas, peneliti menggunakan rumus Chi-Square. Berdasarkan perhitungan, ditemukan harga chi $\mathrm{c}_{\text {hitung }}=5,88$. Harga tersebut selanjutnya dibandingkan dengan chitabel dengan d.b $=6-1=5$ pada taraf signifikansi $5 \%$, maka harga chi ${ }_{\text {hitung lebih kecil dari }}$ harga chi tabel $=11,070$. Dapat disimpulkan bahwa harga chi $_{\text {hitung }}$ lebih kecil dari harga chi tabel $(5,88<11,070)$, maka nilai pretest dikatakan normal. Berdasarkan perhitungan, ditemukan harga chi hitung $=10,53$. Harga tersebut selanjutnya dibandingkan dengan chi tabel $_{\text {dengan }}$ d. $b=6-$

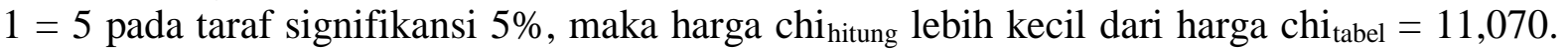
Dapat disimpulkan bahwa harga chi ${ }_{\text {hitung }}$ lebih kecil dari harga chi tabel $(10,53<11,070)$, maka nilai posttest dikatakan normal.

Setelah melakukan perhitungan uji normalitas, maka selanjutnya peneliti melakukan penghitungan uji hipotesis. Uji t-test dilakukan dengan menghitung selisih atau beda hasil posttest dan pretest. setelah melakukan perhitungan t-test diperoleh nilai thitung sebesar 10,027. Dengan $\mathrm{db}=25$, pada taraf signifikansi 5\% diperoleh $\mathrm{t}_{\text {tabel }}$ sebesar 2,055. Maka dapat disimpulkan bahwa $t_{\text {hitung }}>\mathrm{t}_{\text {tabel }}(10,027>2,055)$ artinya $\mathrm{H}_{0}$ tidak terbukti dan $\mathrm{H}_{1}$ terbukti. $\mathrm{H}_{0}$ yang menyatakan bahwa tidak terdapat perbedaan signifikan antara hasil menulis deskripsi siswa dengan menggunakan media pop-up. $\mathrm{H}_{1}$ yang menyatakan bahwa terdapat perbedaan signifikan antara menulis deskripsi siswa dengan menggunakan media pop-up, Sehingga dapat disimpulkan bahwa $\mathrm{H}_{1}$ yang menyatakan bahwa terdapat perbedaan signifikan antara hasil menulis deskripsi siswa dengan menggunakan media pop-up dengan yang tidak menggunakan perlakuan (media рор-ир) diterima, artinya media рор-ир berpengaruh terhadap keterampilan menulis deskripsi siswa kelas III SDIT At-Taqwa Surabaya.

Di bawah ini adalah diagram nilai rata-rata pretset

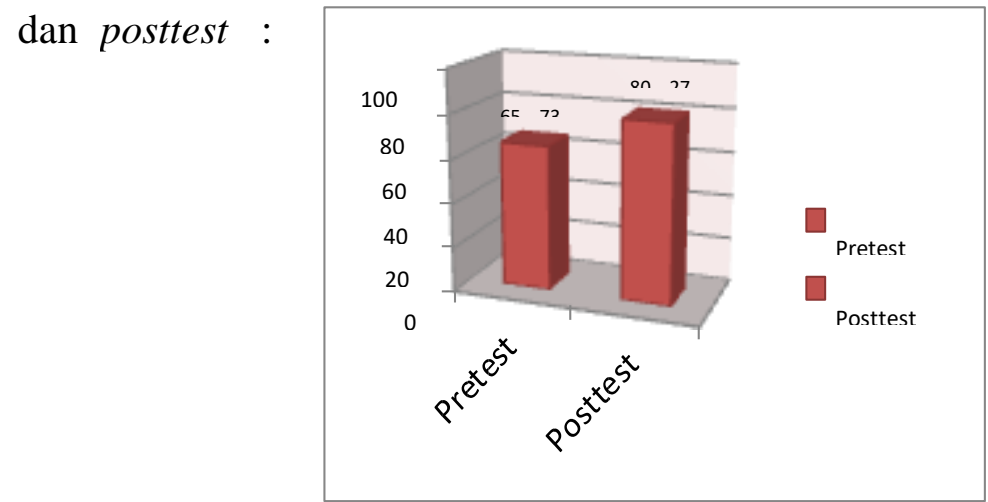

Diagram 1. Perbandingan Rata-Rata Kelas Nilai Pretest-Posttest

Dari diagram 1 tersebut menunjukkan rata-rata nilai pretest dan posttest siswa kelas IIIB. Rata-rata nilai pretest (tes awal) adalah 65,73 sedangkan setelah dilakukan perlakuan dengan media pop-up maka hasil posttest siswa menjadi 80,27. Dari rata-rata di atas dapat diketahui bahwa peningkatan hasil menulis deskripsi sebesar 14,54. Berdasarkan hasil tersebut diketahui bahwa keterampilan menulis deskripsi mengalami peningkatan yang signifikan. 
Faktor yang mempengaruhi tingginya nilai posttest dibanding nilai pretest adalah penggunaan media pop-up yang membantu mempermudah siswa dalam merangsang daya imajinasi dan mengembangkan kreativitas siswa dalam menulis deskripsi.

Hasil analisis secara statistik juga menunjukkan hasil yang sama. Analisis statistik menggunakan rumus uji t. Hasil dari perhitungan uji t dengan membandingkan atau menghitung perbedaan nilai pretest dan posttest. Dari hasil tersebut diketahui harga $t_{\text {hitung }}=10$, 027 dengan taraf signifikan $5 \%$ dan $\mathrm{db}=26-1=25$ diperoleh harga $t_{\text {tabel }}=2,060$. Hal ini menunjukkan bahwa $t_{\text {hitung }}$ lebih besar daripada $t_{\text {tabel }}$ yaitu 10,027 $>2,060$. Berdasarkan hasil tersebut dapat disimpulkan bahwa hasil uji beda (uji t) pembelajaran menggunakan media popup berpengaruh terhadap keterampilan menulis deskripsi.

\section{KESIMPULAN}

Berdasarkan hasil penelitian dan pembahasan tentang pengaruh media pop-up terhadap keterampilan menulis deskripsi tema bumi dan alam semesta siswa kelas III SDIT At-Taqwa Surabaya yang telah dideskripsikan pada bab IV, maka diperoleh simpulan penggunaan media pop-up terlaksana dengan baik sekali. Hal ini dibuktikan dengan perhitungan pada tabel kontingensi kesepakatan antara pengamat 1 dan pengamat II yaitu hasil perhitungan sebesar 0,943 . Tes keterampilan menulis deskripsi siswa setelah diberi perlakuan berupa penggunaan media рор-up memiliki hasil yang lebih baik dari pada hasil tes keterampilan menulis deskripsi sebelum diberi perlakuan. Nilai pretest berjumlah 1709 dengan rata-rata kelas sebesar 65,73 dan nilai posttest berjumlah 2087 dengan rata-rata kelas sebesar 80,27. Artinya perbedaan penggunaan media pop-up dalam pembelajaran mempunyai pengaruh yang signifikan terhadap keterampilan menulis deskripsi siswa. Hal ini juga didukung dengan pengujian statistik menggunakan uji t. Hasil uji t menunjukkan bahwa hipotesis kerja yang telah dirumuskan diterima. Diketahui harga $t_{\text {hitung }}=10,027 \mathrm{dan} \mathrm{db}=26-1=25$ diperoleh harga $\mathrm{t}_{\text {tabel }}=2,060$ (pada taraf signifikansi 5\%), sehingga di peroleh $(10,027>2,060)$.

Berdasarkan hasil tersebut maka dapat disimpulkan bahwa hasil uji beda (uji t) dengan menggunakan media pop-up berpengaruh terhadap keterampilan menulis deskripsi siswa kelas III-B SDIT At-Taqwa Surabaya.

\section{DAFTAR PUSTAKA}

Afandi Pandi (2016). Compect dan indikator. Human resources Management Yogyakarta: DEEPUBLISH

Arikunto, Suharsini. 2010. Prosedur Penelitian Suatu Pendekatan Prakmatik. Jakarta: PT. Rineka Cipta.

Arsyad, Azhar. 2014. Media Pembelajaran. Jakarta: PT. Raja Grafindo Persada.

Dalman. 2015. Keterampilan Menulis. Jakarta: PT Raja Grafindo Persada.

Dzuanda. 2011. Design Pop-up Child Book Puppet Figure Series?Gatotkaca?. Jurnal Library ITS Undergraduate (Online),(http://library.its.undergraduate.ac.id, diakses pada 16 Desember 2015. 
Nurgiyantoro, Burhan. 2012. Penilaian Pembelajaran Bahasa Berbasis Kompetensi. Yogyakarta: UNY Press.

Tarigan, Henry Guntur. 2008. Menulis. Bandung: Angkasa.

Undang-undang No 32 Tahun 2013 tentang sistem pendidikan nasional (sisdiknas). Diakses 23 Februari 2020

Winarsunu, T. 2009. Statistik dalam Penelitian Psikologi Pendidikan. Malang: UMM Press. 